\title{
B Lymphoblastic Lymphoma
}

National Cancer Institute

\section{Source}

National Cancer Institute. B Lymphoblastic Lymphoma. NCI Thesaurus. Code C8868.

An uncommon type of lymphoma. It constitutes approximately $10 \%$ of cases of lymphoblastic lymphoma. Approximately $75 \%$ of cases reported in a literature review involved patients who were less than 18 years of age. The most commonly affected sites are the skin, bone, soft tissue, and lymph nodes. It has a high remission rate with a median survival of approximately 60 months. (WHO, 2001) 